\title{
CROWDFUNDING PLATFORMS IN US AND EU: EMPIRICAL ANALYSIS OF SOCIAL CAPITAL
}

\begin{abstract}
The present work aims to investigate the crowdfunding phenomenon, deepening the implications for the various stakeholders deriving from this funding collection mechanism and the role it has assumed in recent years, especially in the processes of business creation and spread of entrepreneurship. It also seeks to extend the literature that is still at an early stage, as well as to broaden the knowledge of areas that are under-research and on which clarity has not been made completely. For doing this we analyze, through a dataset of 103 projects, the qualities of the founders (project proponents) and funders, which determine the amount obtained in successful, or funded, initiatives. The objective of this research project is to analyze the internal social capital created in the platforms, represented by the bonds established by the founders and funders, measured in terms of supported projects, followed and created previously by both actors (all with reference to a date prior to the launch of the initiative analyzed), and how it affects the result of the initiative, or on the capital raised.
\end{abstract}

Keywords: crowdsourcing, crowdfunding platforms, social capital, stakeholders, startup, Ulule, Kickstarter

Oklahoma University, Union College-NY;

irene.liakopoulou@eclipso.be 


\section{Introduction}

Crowdfunding is a funding mechanism through the crowd, which originates from crowdsourcing ${ }^{1}$. Fundraising takes place on special online platforms, promoting interaction between the various actors involved in the mechanism ${ }^{2}$. This form of bottom-up financing allows anyone to be able to perform a first test on the validity of their business idea or to test products and obtain the necessary financial resources without financial intermediaries ${ }^{3}$.

Thanks to crowdfunding, in fact, people with ideas can have an initial push to start (a start-up push), giving importance also to those who have not been taken into consideration by traditional credit access channels, the so-called "long tail"4

The main crowdfunding platforms, including Ulule and Kickstarter, two of the best known reward-based models in the world (respectively they have been considered one of the first in Europe and one of the first in the United States), show a trend of projects presented in constant growth, as the number of supporters has risen significantly, highlighting above all a "globalization" effect which has now led to the participation of people from all parts of the world in the initiatives.

Currently the members of the community on Ulule are over 2,852,709 from 195 countries, and the total funds raised, since the creation of the platform, are over 159 million euros, highlighting a constantly increasing trend over the years (see Figure 1). In fact, the increase in funds raised in 2017 was $11.57 \%$ compared to 2016 (going from 25.09 to 27.99 million euros), in $201810.54 \%$ compared to

1 Crowdsourcing is the act of a company or institution to take a function traditionally performed by employees and outsource it to an indefinite (generally large) network of people in the form of an open call. This in turn can take on the structure of peer-production or social production (with the work done collaboratively), but often it is also undertaken by a single individual. Crowdsourcing therefore allows the power of the crowd to conclude tasks that were once the field of competence of a few specialists. Using other words, it consists of taking the principles used in open source software projects and applying them to the whole spectrum of the business world. The fundamental prerequisite is the use of the open call format and the vast network of potential workers. For further details see: Safire, W., (2009): On Language, New York Times Magazine. Howe, J., (2008): Crowdsourcing: Why the Power of the Crowd Is Driving the Future of Business, Crown Publishing Group, NY. Kuppuswamy, V., Bayus, B.L., (2013): Crowdfunding creative ideas: The dynamics of project backers in Kickstarter, UNC Kenan Flager Research Paper, n. 2013-15, SSRN Electronic Journal, 1-37.

2 Agrawal, A., Catalini, C., Goldfarb, A., (2013): Some Simple Economics of Crowdfunding, Innovation Policy and the Economy, NBER Books, National Bureau of Economic Research, 14, 63-97. Mollick, E., (2014): The dynamics of crowdfunding: An exploratory study, Journal of Business Venturing, 29, 1-16.

3 Lambert, T., Schwienbacher, A., (2014):Crowdfunding: Tapping the right crowd, Journal of Business Venturing, 29, 585-609.

4 Vassallo, W., (2016): Crowdfunding nell'era della conoscenza. Chiunque può realizzare un progetto. Il futuro è oggi, Franco Angeli, Milan,112. 
2017 (going from 27.99 to 30.94 million euros), and finally in 2019 it shows for the first time a slight decrease of $-6.07 \%$ compared to 2018 (going from 30.94 to 29.07 million euros).

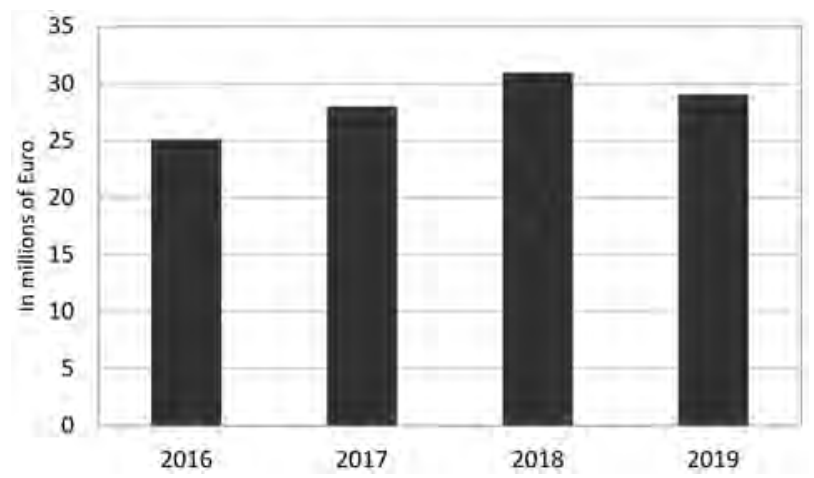

Source: Processing by the author on Ulule data

Figure 1: The funds raised on the Ulule platform

In the Kickstarter platform (USA), there are currently 17,457,963 members of the community, and the total funds raised since the platform's creation are $4,798,290,228$ dollars, highlighting a mixed trend over the years (Figure 2). We start with a small decrease of $-5.61 \%$ from 2015 to 2016 (going from 686.17 to 649.69 million dollars), next year the increase in funds raised in 2017 is $1.43 \%$ compared to 2016 (going from 649.69 to 659.15 million dollars) and in 2018 there is again a small decrease of $-8.59 \%$ compared to 2017 (going from 659.15 to 606.99 million dollars).

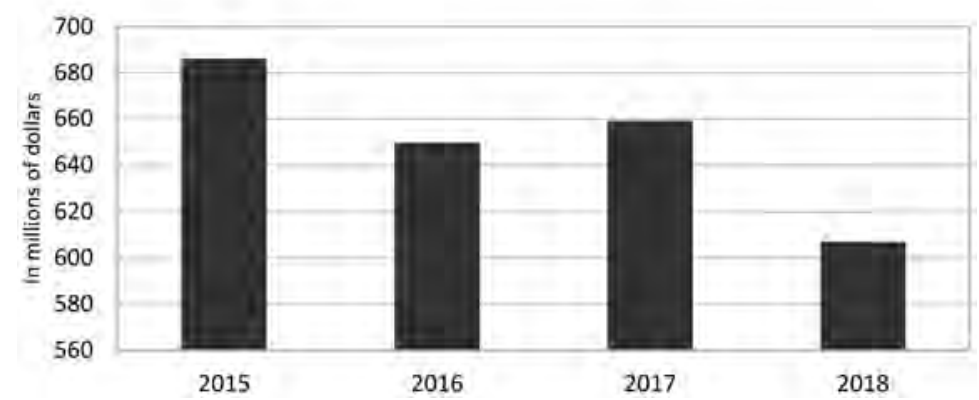

Source: Processing by the author on Kickstarter data (ICO Partners)

Figure 2: Funds collected on the Kickstarter platform

As for the number of projects presented on the Ulule platform, since its entry into the market, the overall average success rate is 66\%, and in the last year it has been $71 \%$. Also in this case there is a growing trend regarding the number of projects presented (Figure 3). In fact, there is an increase in projects in 2017 of $5.43 \%$ compared to 2016 (going from 7.056 to 7.461 ), in 2018 of $7.58 \%$ compared 
to 2017 (going from 7.461 to 8.073), in 2019 it is highlighted however a drastic drop of $33.02 \%$ compared to 2018 (going from 8,073 to 6,069). Finally, at February 2020 the number of projects published on Ulule are 584 .

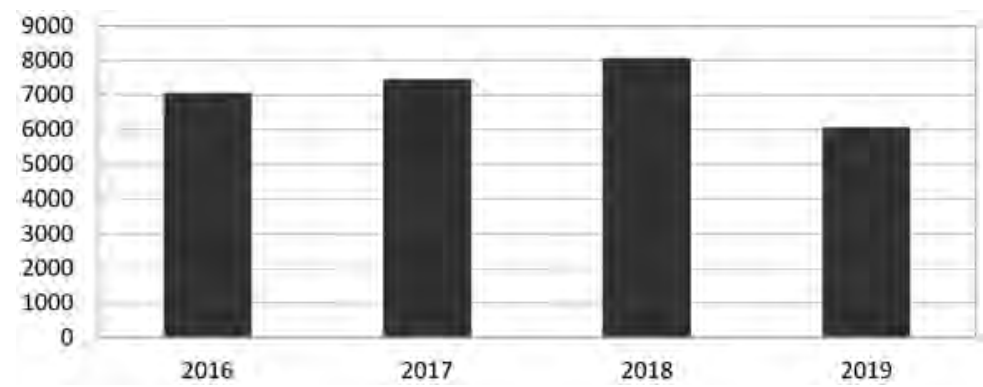

Source: Elaboration by the author on Ulule

Figure 3: Projects published on the Ulule platform

With reference to the Kickstarter portal (see Figure 4), after a considerable increase from 2009 to 2015 the number of projects has decreased from 2015 onwards even if the numbers of projects presented remain at high levels. Specifically, in absolute numbers, there is a decrease of $-33.0 \%$ in 2016 compared to 2015 (going from 77.327 to 58.139 ), $-9.45 \%$ in 2017 compared to 2016 (going from 58.139 to 53.116), and finally - 19.35\% in 2018 compared to 2017 (going from 53.116 to 44.503).

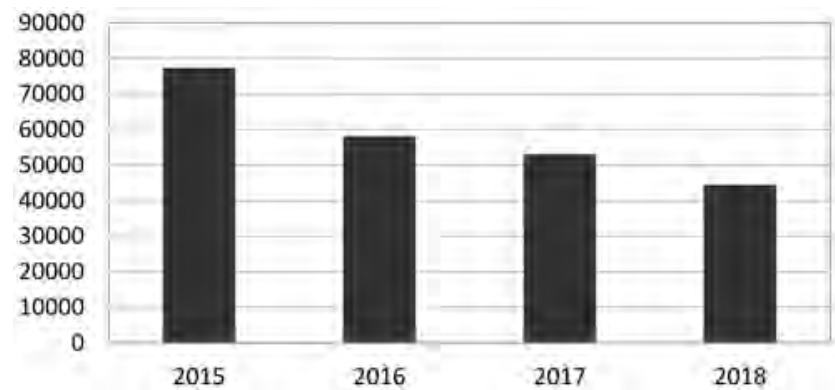

Source: Processing by the author on Kickstarter data (ICO Partners)

Figure 4: Projects published on the Kickstarter platform

A further particularly significant element, which highlights the dimensions of the crowdfunding phenomenon, is represented by the number of supporters who have financed online projects, in fact, referring for example to one of the first and most important portals on the world scene such as Kickstarter, it is noted that the total number of supporters is $17,457,963$ from almost all countries of the world ${ }^{5}$.This spread is favored by the expansion of social networks ${ }^{6}$.

Kickstarter statistics updated on 01/02/2020.

6 Colombo, M.G., Franzoni, C., Lamastra, C.R., (2015): Internal Social Capital and the Attraction of Early Contributions in Crowdfunding, Entrepreneurship Theory and Practice, 


\section{Literature review}

Being a new phenomenon, the contributions in literature are at an early stage. Scholars have investigated the reasons that lead both financiers and entrepreneurs to use a crowdfunding "context" .

In this mechanism, the interaction that is created between project proponents, crowdfunding platform and supporters is crucial ${ }^{8}$.

The majority of contributions in the literature analyzed the factors that led to successful cases, i.e. achievement (or exceeding) of the objective, and failure (goal not achieved) of the initiatives?.

Colombo et al. in the "internal social capital and the attraction of early contributions in crowdfunding", highlighted the role of social capital that is created within the crowdfunding platform. According to the authors, in fact, they "are not only intermediaries of economic transactions, but also places of social connections"10. In their contribution, it was highlighted how "internal social capital", represented by the number of projects supported by the proposer before launching its crowdfunding campaign, as opposed to external social capital ${ }^{11}$, affects the success of the initiative by attracting supporters, and therefore favoring the contribution of the first contributions, in the initial phase of the launch of the crowdfunding campaign.

Starting from the existing literature, this chapter presents a contribution that focuses on both founder and funder quality, analyzing how these positively affect the success of the initiative, in terms of funding obtained. These qualities are represented by the share capital both referring to the founders, as partially already analyzed in the literature, albeit with different objectives, and to the funders ${ }^{12}$.

No work previously had also analyzed the qualities of the funders, and in fact there are limited contributions to the analysis of the motivations of the subjects $^{13}$. The intuition of this contribution is that funders' share capital also plays

2015,75-100.

7 Lambert, T., Schwienbacher A., (2014), 590-609. Cholakova, M., Clarysse, B., (2015): Does the Possibility to Make Equity Investments in Crowdfunding Projects Crowd Out RewardBased Investments?,Entrepreneurship Theory and Practice, 39, 145-172.

8 Valanciene, L., Jegeleviciute, S., (2013): Valuation of crowdfunding: Benefits and drawbacks, Economics and Management, 18, 39-48.

9 Mollick, E., (2014), 1-16. Ahlers, G.K.C., Cumming, D., Günther, C., Schweizer, D., (2015): Signaling in Equity Crowdfunding, Entrepreneurship Theory and Practice, 39, 955-980. Cordova, A., Dolci, J., Gianfrate, G., (2015): The determinants of crowdfunding success: evidence from technology projects, Procedia-Social and Behavioral Sciences, 181, 115-124.

10 Colombo, M.G., Franzoni, C., Lamastra, C.R., (2015), 80-100.

11 Agrawal, A., Catalini, C., Goldfarb, A., (2013), 63-97.

12 Colombo, M.G., Franzoni, C., Lamastra, C.R., (2015), 85-100.

13 Cholakova, M., Clarysse, B., (2015), 145-172. 
an important role in the success of crowdfunding initiatives, or in the amount of funding obtained. The purpose of this chapter is to contribute to the current debate on crowdfunding and social capital, a topic addressed by different schol$\mathrm{ars}^{14}$ in different areas, but still not very detailed with reference to the new forms of financing that have emerged in recent years, in particular to crowdfunding. The work aims to shed light on the role of the two interpreters of this mechanism and the correlation with the funding received from the lenders.

\section{Evolution of lenders}

In the literature there are several contributions that have placed the focus on the founders, analyzing the reasons for the decisions to use the crowdfunding platforms to obtain funding ${ }^{15}$, while there are few contributions in reference to the "crowd", in particular by analyzing their motivations, financial and otherwise, which push them to invest ${ }^{16}$, and highlighting the "transformation" of the crowd into "investors"17 and "small business angels"18. There are no considerations on a possible transformation of the lenders into "project proponents" and/ or "entrepreneurs". Thanks to funding from the crowd, both projects and the number of promoters have increased, a mechanism that over the years has led to a constant increase in the size of the phenomenon, as previously mentioned in numerical terms.

The growing number of founders, who previously supported (see Colombo et al.) or followed initiatives, highlights a sort of "contamination" effect, which leads more and more subjects to launch their business idea or create their own business after the experience carried out as financiers, and driven by a spirit of emulation and by the possibility of carrying out a test on the market at zero $\operatorname{cost}^{19}$.

Crowdfunding seems to represent a tool that therefore stimulates funders to promote projects themselves, for example by trying to implement their ideas (business, social, etc.), thus becoming themselves founders. A possible interpre-

$14 \quad$ Lin, N., (2001): Social capital. A theory of social structure and action, Cambridge University Press, Cambridge.

15 Gerber, E.M., Hui, J.S., Huo, P.Y., (2012): Crowdfunding:Why People Are Motivated to Post and Fund Projects on Crowdfunding Platforms, Proceedings of the International Workshop on Design, Influence, and Social Technologies:Techniques , Impacts and Ethics, Academic Press.

16 Cholakova, M., Clarysse, B., (2015), 155-172.

17 Ordanini, A., Miceli, L., Pizzetti, M., Parasuraman, A., (2011) Crowd-Funding: Transforming Customers into Investors through Innovative Service Platforms, Journal of Service Management , 22, 443 - 470.

18 Hornuf, L., Schwienbacher, A., (2014): Crowdinvesting-Angel Investing for the Masses?, Handbook of Research on Venture Capital: vol. 3. Business Angels.

19 Colombo, M.G., Franzoni, C., Lamastra, C.R., (2015), 78-100. 
tation of the phenomenon is therefore linked to the possibility that crowdfunding is a tool that stimulates "entrepreneurship", since sometimes in funders "shaken" by the example of others, ideas arise, both entrepreneurial ones and in response to certain needs that have emerged and for which a solution has been found.

In this regard, in fact, analyzing the projects presented on the Ulule platform in the four categories used for the dataset (i.e. technology, games, fashion \& design and crafts \& foods), it emerges that over a quarter of the supporters subsequently in turn become proposer of a project or more projects. A further significant fact is that the same new "promoters" launch campaigns in different categories, therefore not focusing on a specific type of activity.

\section{Methodology, hypotheses and research objectives}

The objective, at this point of the work, is to analyze the qualities of the founders and funders, or the social capital of the same, represented by the bonds established previously in the crowdfunding campaign. These qualities measured in terms of supported projects, followed and created previously by both authors (all with reference to the date prior to the launch of the analyzed initiative), can influence the result of the initiative, or have an impact on the capital raised (dependent variable). Compared to the existing literature, this work aims to verify, in successfully funded projects, the correlation of internal social capital (created in the platform) by both the founders and the funders, with the final amount of funding raised (Figure 5).
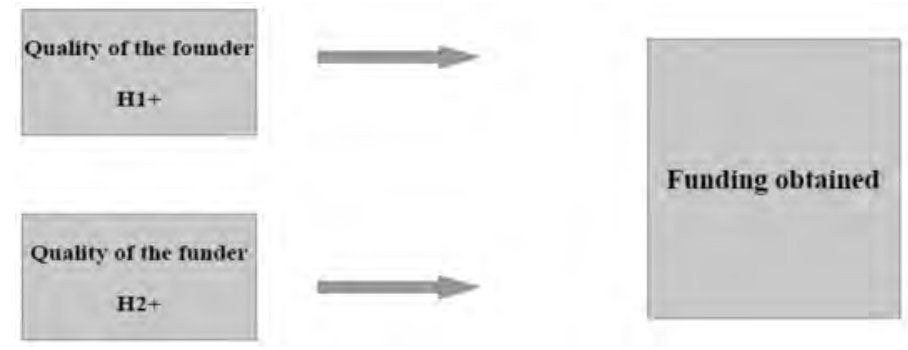

Source: Processing by the author

Figure 5: The factors that determine the amount of funding obtained

In this work, it is argued that the funding received is positively correlated with the quality of both the founder and the funder, and we proceed with the formulation of the following two hypotheses.

Hypothesis 1: The qualities of the founders positively influence the total funding raised.

Hypothesis 2: The qualities of the funders positively influence the total funding raised. 
The founders' quality category includes the projects created, supported and followed by the founders prior to the launch of the campaign.

The funder quality category includes the projects created and followed by the funders before supporting the campaign, and in addition to representing the previously supported projects, two important variables were identified, namely the number of expert funders (who supported at least one project in previously), the number of projects financed by expert funders and also the number of new supporters is indicated, that is, those who for the first time signed up to the platform and supported an initiative.

Further variables related to control concern updates, comments, the funding objective (the minimum target expected to be reached in order to consider a funded campaign) and the average contribution, already used in literature ${ }^{20}$.

\subsection{Sample and data collection}

The dataset was created considering all the projects presented on the Ulule platform, one of the main crowdfunding reward based portals in Europe, examining the projects presented in 2018 (from January to December) in reference to the "technology", "games","fashion \& design" and "crafts \& foods", considered identifying different areas and macro-categories present on the platform, and more generally of the main categories supported through crowdfunding. The final sample obtained is 103 successfully funded projects (including 20 in the technology category, 46 in the games category, 20 in the fashion \& design category and 17 in the crafts \& foods category).

\section{Description of the variables}

Dependent variable:

- Ln Funding: the logarithmic transformation (natural logarithm) of the total funding raised by the initiatives.

Independent variables:

- 1.Ln Goal: The logarithm of the amount of funding requested, or the goal to be achieved in order to be financed successfully;

- 2.Ln Average amount: The logarithm of the average amount of contributions from each lender;

- 3.Founder Star: The number of founders who previously supported more than one project and have a "badge" (attributed by the platform based on the activity carried out and the role acquired within it);

- $\quad$ 4.Created by the founder: The number of projects created by the founder before the launch of the campaign;

$20 \quad$ Mollick, E., (2014), 5-16. 
- 5.Supported by the founder: The number of projects supported by the founder before the launch of the campaign;

- $\quad$ 6.Followed by the founder: The number of projects followed by the founder before the launch of the campaign;

- 7.Funder experts: The number of supporters who previously funded at least one project;

- $\quad$ 8.Financed by expert funders: The number of projects previously funded by expert funders;

- 9.Created by funders: The number of projects created by funders previously;

- 10. Followed by the funder: The number of projects followed by the funder previously;

- 11.New supporters: The number of newly enrolled supporters who finance a project for the first time;

- 12.Comments: The number of comments written by the lenders (and to which the founder may or may not have replied);

- 13.News: The number of updates entered by the founder.

Table 1: Descriptive statistics

\begin{tabular}{|l|c|r|r|r|r|}
\hline Variables & Obs & Mean & Std. Dev. & Min & Max \\
\hline Ln Funding & 103 & 7.976164 & 1.06023 & 5.703782 & 11.61498 \\
\hline Ln Goal & 103 & 7.655348 & 1.014757 & 5.29909 & 11.51967 \\
\hline Ln Average Amount & 103 & 3.86348 & .5626244 & 2.515147 & 5.765613 \\
\hline Founder Star & 103 & .1650485 & .3730396 & 0 & 1 \\
\hline Created by the founder & 103 & .4951456 & 1.798004 & 0 & 11 \\
\hline Supported by the founder & 103 & .9902913 & 1.629959 & 0 & 9 \\
\hline Followed by the founder & 103 & 1.572816 & 2.435851 & 0 & 12 \\
\hline Expert funders & 103 & 14.4466 & 24.60501 & 0 & 181 \\
\hline Funded by expert funders & 103 & 75.27184 & 86.10484 & 0 & 537 \\
\hline Created by funders & 103 & .3786408 & 1.103617 & 0 & 10 \\
\hline Followed by funders & 103 & 15.02913 & 21.15603 & 0 & 97 \\
\hline New Supporters & 103 & 95.52427 & 265.3662 & 4 & 2646 \\
\hline Comments/Notes & 103 & 63.31068 & 173.1191 & 0 & 1381 \\
\hline News & 103 & 11.1165 & 11.25141 & 0 & 50 \\
\hline
\end{tabular}

Note: This table shows the descriptive statistics regarding the successfully funded reward crowdfunding projects. It shows the mean (mean), the standard deviation (Std. Dev.) and the minimum (min) and maximum $(\max )$ values for each variable used. 
Table 2: Correlation matrix and VIF

\begin{tabular}{|c|c|c|c|c|c|c|c|c|c|c|c|c|c|c|c|}
\hline \multicolumn{15}{|c|}{$(1-14)$} & \multirow[t]{2}{*}{ VIF } \\
\hline 1.Ln Funding & 1.0000 & & & & & & & & & & & & & & \\
\hline 2.Ln Goal & 0.8972 & 1.0000 & & & & & & & & & & & & & 2.78 \\
\hline 3.Ln Av. Amount & 0.5291 & 0.4815 & 1.0000 & & & & & & & & & & & & 1.78 \\
\hline 4.Founder Star & 0.0253 & -0.0761 & 0.0125 & 1.0000 & & & & & & & & & & & 1.92 \\
\hline 5.Cr. by founder & 0.1616 & 0.0280 & 0.0270 & 0.6224 & 1.0000 & & & & & & & & & & 3.13 \\
\hline 6.Sup. by founder & 0.6437 & 0.5377 & 0.2373 & 0.2284 & 0.2325 & 1.0000 & & & & & & & & & 3.00 \\
\hline 7.Fol. by founder & 0.5621 & 0.5153 & 0.2336 & 0.2726 & 0.2950 & 0.7323 & 1.0000 & & & & & & & & 2.81 \\
\hline 8.Expert funders & 0.5402 & 0.3289 & 0.1220 & 0.3380 & 0.6405 & 0.5208 & 0.4445 & 1.0000 & & & & & & & 4.86 \\
\hline 9. F. ex. Funders & 0.4538 & 0.3176 & 0.1393 & 0.3044 & 0.4449 & 0.4984 & 0.4390 & 0.7161 & 1.0000 & & & & & & 2.71 \\
\hline 10.Cr. By funders & -0.0667 & -0.0759 & -0.1790 & -0.0342 & -0.0806 & 0.0675 & 0.0753 & 0.0233 & -0.0250 & 1.0000 & & & & & 1.10 \\
\hline 11.Fol. by funders & 0.6189 & 0.5151 & 0.0459 & 0.0106 & 0.2324 & 0.5371 & 0.5130 & 0.5883 & 0.5454 & 0.0432 & 1.0000 & & & & 2.52 \\
\hline 12. New sup. & 0.5098 & 0.5246 & -0.0314 & -0.0505 & -0.0023 & 0.3567 & 0.4177 & 0.2966 & 0.1104 & 0.0586 & 0.5151 & 1.0000 & & & 2.08 \\
\hline 13.Com./Notes & 0.4591 & 0.3090 & 0.1050 & 0.3235 & 0.6248 & 0.5123 & 0.3680 & 0.8040 & 0.5838 & -0.0503 & 0.5171 & 0.2610 & 1.0000 & & 3.45 \\
\hline 14.News & 0.5041 & 0.3020 & 0.3352 & 0.1682 & 0.2884 & 0.4700 & 0.4315 & 0.5239 & 0.5373 & -0.0060 & 0.3573 & 0.1397 & 0.4626 & 1.0000 & 1.77 \\
\hline
\end{tabular}

Mean VIF 2.61

$\mathrm{p} \leq .05$

VIF, variance inflation factor

The average VIF is 2.61 and single values are lower than the critical thresholds (5-6), therefore there are no problems related to multicollinearity.

\section{Analysis and results}

The OLS Regression method was used for this work, since the dependent variable follows a normal distribution. In the model robust standard errors were used and there are no problems related to multicollinearity, recording an average VIF of 2.61 and the individual values are lower than the critical thresholds ${ }^{21}$ as shown in table 3. The model is statistically significant ${ }^{22}$ and the $\mathrm{R}^{2}$ index is equal $91 \%$.

With reference to the first hypothesis, i.e. the qualities of the founder, the only significant variable is represented by the number of projects previously supported by the founder (coeff. 0.0823 which corresponds to an increase of approximately $8.6 \%$ of the funding for a increase of one unit of the projects supported by the founder). It positively affects the amount of funding raised and partially confirms the first hypothesis.

As regards the qualities of the lenders, both the number of projects followed by the funders previously (coeff. 0.0064 corresponding to an increase of approximately $0.65 \%$ of the funding for a unitary increase of projects followed by the funders) and the number of expert funders (coeff. 0.0106 or an increase of approximately $1.1 \%$ of the funding for an increase of one unit of expert supporters), are positively correlated, albeit with a small impact, on the funding obtained, confirming even if in the second hypothesis is minimal.

\footnotetext{
21 Values above 5 and 6 can highlight problems related to multicollinearity.

22 (Prob F > 0.0000).
} 
This evidence shows how the share capital of the founder and funders constitute relevant elements in the success of the initiative. In fact, the number of expert supporters for example represents a quality element for the project, since the presence of these subjects can somehow attract other financiers, and therefore a greater number of contributions, thanks to the links previously created by the funders (who have already financed more than one project). Even the projects supported by the founders previously are a sign of the bonds that it has previously established, precisely through the support given to other initiatives.

\section{Table 3: Model 1}

$$
\begin{aligned}
\text { Number of obs } & =103 \\
\text { F }(14,93) & =107.35 \\
\text { Prob }>\text { F } & =0.0000 \\
\text { R-squared } & =0.9174 \\
\text { Root MSE } & =0.32613
\end{aligned}
$$

\begin{tabular}{lrrrrrr}
\hline & Coef. & \multicolumn{1}{c}{$\begin{array}{c}\text { Robust } \\
\text { Std. Err. }\end{array}$} & \multicolumn{1}{c}{$\mathbf{t}$} & $\mathbf{P}>\mathbf{t}$ & \multicolumn{1}{c}{$\begin{array}{l}\text { C95\% } \\
\text { Conf. }\end{array}$} & Interval \\
\hline Ln Goal & .6690645 & .0707212 & 9.46 & 0.000 & .528543 & .8095859 \\
Ln Average Amount & .274633 & .0707786 & 3.88 & 0.000 & .1339975 & .4152685 \\
Founder Star & .0686498 & .1513774 & 0.45 & 0.651 & -.2321339 & .3694336 \\
Created by the founder & -.0180831 & .0344826 & -0.52 & 0.601 & -.0865992 & .050433 \\
Supported by the founder & .0823176 & .0316098 & 2.60 & 0.011 & .0195096 & .1451256 \\
Followed by the founder & -.0358209 & .0183999 & -1.95 & 0.055 & -.0723812 & .0007394 \\
Expert funders & .0106837 & .0040045 & 2.67 & 0.009 & .0027269 & .0186406 \\
Financing by expert funders & -.0008735 & .000578 & -1.51 & 0.134 & -.002022 & .0002749 \\
Created by the funders & -.0137082 & .0153393 & -0.89 & 0.374 & -.0441871 & .0167707 \\
Followed by the funders & .0063735 & .0029483 & 2.16 & 0.033 & .0005152 & .0122318 \\
New supporters & .0001559 & .000175 & 0.89 & 0.375 & -.0001917 & .0005036 \\
Comments/Notes & -.0004534 & .0004425 & -1.02 & 0.308 & -.0013327 & .0004258 \\
News & .012639 & .0055786 & 2.27 & 0.026 & .0015544 & .0237235 \\
cons & 1.459768 & .4530868 & 3.22 & 0.002 & .5594945 & 2.360042 \\
\hline p<0.05 & & & & & &
\end{tabular}

\section{Conclusions and implications}

This work lends itself to contributing to the current debate on the role of social capital and the factors linked to the success of the initiatives proposed on the crowdfunding portals, showing an analysis that also refers to the social capital of funders, and not only that of the founders. The work represents an extension of the literature on internal social capital in crowdfunding, expanding and implementing the previous considerations proposed by a previous paper 
with reference to the qualities of the founders, while with reference to the social capital of the funders the contribution presents considerations hitherto absent on theme.

As for the qualities of the founders, this work shows how they, represented by the previously supported projects (variable identified as "internal social capital" by Colombo et al., as an expression of the degree of the supported projects), positively influence the amount of funding raised, and additional elements representative of the qualities of the founder such as the projects created and followed previously have also been taken into consideration (albeit without impact). The results emerged therefore broaden the current knowledge on the topic, which had hitherto highlighted how the internal share capital of the founder favored the success of the initiatives by showing a positive correlation in the initial stages of the launch of the initiative, i.e. on the first financiers involved and therefore the first contributions received.

With reference instead to the qualities of the funders, this contribution highlights the existence of a "stock" of social capital that has been created within the crowdfunding platforms, also considering the funders, who, like the founders, have supported, created or followed previously by crowdfunding campaigns, thus establishing a series of connections with the various users of this funding collection mechanism. In particular, both the number of projects previously followed by the funders and the number of expert funders, that is, who have supported more than one project previously, are positively correlated, albeit to a limited extent, with the funding received.

This work therefore highlights the importance of internal social capital in this crowd funding mechanism, as opposed to previous contributions, such as those of Agrawal et $\mathrm{al}^{23}$ and Mollick ${ }^{24}$, which had paid attention with reference to only "external share capital".

Furthermore, this contribution also focuses on the prospects of the funders, through a consideration of the possible business implications of the same deriving from the use of this tool.

The contribution may have interesting implications for the managers of the crowdfunding platforms, which favor the connections between the subjects, but also for the funders and the founders. In particular, the latter receive useful information on the factors that influence the success of the initiatives launched.

A future development of this work consists of an in-depth analysis of the trade off of new supporters - supporters already present within the community, to analyze whether, under pawns of conditions, one of the two categories has a greater influence on the success of the initiatives.

\footnotetext{
23 Agrawal, A., Catalini, C., Goldfarb, A., (2013), 80-97.

24 Mollick, E., (2014), 1-16.
} 


\section{Literature}

- Ahlers, G.K.C., Cumming, D., Günther, C., Schweizer, D., (2015): Signaling in Equity Crowdfunding, Entrepreneurship Theory and Practice, 39, 955-980.

- Agrawal, A., Catalini, C., Goldfarb, A., (2013): Some Simple Economics of Crowdfunding, Innovation Policy and the Economy, NBER Books, National Bureau of Economic Research, 14, 63-97.

- Cholakova, M., Clarysse, B., (2015): Does the Possibility to Make Equity Investments in Crowdfunding Projects Crowd Out Reward-Based Investments?,Entrepreneurship Theory and Practice, 39, 145-172.

- Colombo, M.G., Franzoni, C., Lamastra, C.R., (2015): Internal Social Capital and the Attraction of Early Contributions in Crowdfunding,Entrepreneurship Theory and Practice, 2015,75-100.

- Cordova, A., Dolci, J., Gianfrate, G., (2015): The determinants of crowdfunding success: evidence from technology projects, Procedia-Social and Behavioral Sciences, 181, 115-124.

- Howe, J., (2008): Crowdsourcing: Why the Power of the Crowd Is Driving the Future of Business, Crown Publishing Group, NY.

- Gerber, E.M., Hui, J.S., Huo, P.Y., (2012): Crowdfunding: Why People Are Motivated to Post and Fund Projects on Crowdfunding Platforms, Proceedings of the International Workshop on Design, Influence, and Social Technologies: Techniques, Impacts and Ethics, Academic Press.

- Hornuf, L., Schwienbacher, A., (2014): Crowdinvesting-Angel Investing for the Masses?, Handbook of Research on Venture Capital: vol. 3. Business Angels.

- Kuppuswamy, V., Bayus, B.L., (2013): Crowdfunding creative ideas: The dynamics of project backers in Kickstarter, UNC Kenan Flager Research Paper, n. 2013-15, SSRN Electronic Journal, 1-37.

- Lambert, T., Schwienbacher, A., (2014): Crowdfunding: Tapping the right crowd, Journal of Business Venturing, 29, 585-609.

- Lin, N., (2001): Social capital. A theory of social structure and action, Cambridge University Press, Cambridge.

- Mollick, E., (2014): The dynamics of crowdfunding: An exploratory study, Journal of Business Venturing, 29, 1-16.

- Ordanini, A., Miceli, L., Pizzetti, M., Parasuraman, A., (2011) Crowd-Funding: Transforming Customers into Investors through Innovative Service Platforms, Journal of Service Management, 22, 443 - 470.

- Safire, W., (2009): On Language, New York Times Magazine.

- Valanciene, L., Jegeleviciute, S., (2013): Valuation of crowdfunding: Benefits and drawbacks, Economics and Management, 18, 39-48.

- Vassallo, W., (2016): Crowdfunding nell'era della conoscenza. Chiunque può realizzare un progetto. Il futuro è oggi, Franco Angeli, Milan,112. 


\section{PLATFORME ZA MASOVNO FINANSIRANJE U SAD I EU: EMPIRIJSKA ANALIZA SOCIJALNOG KAPITALA}

Sažetak: Cilj ovog rada je da istraži fenomen masovnog finansiranja, produbljujući implikacije na različite zainteresovane strane koje proizilaze iz ovog mehanizma prikupljanja sredstava i ulogu koju je preuzeo poslednjih godina, posebno u procesima stvaranja preduzeća i širenja preduzetništva. Takođe se želi proširiti literatura koja je još uvek u ranoj fazi, kao i proširiti znanje o oblastima koje su nedovoljno istražene i koje nisu u potpunosti razjašnjene. Zato analiziramo, kroz skup podataka od 103 projekta, kvalitete osnivača (predlagača projekata) i donatora, koji određuju iznos dobijen u uspešnim ili finansiranim inicijativama. Cilj ovog istraživačkog projekta je da analizira unutrašnji društveni kapital stvoren na platformama, predstavljen obveznicama koje su osnovali osnivači i finansijeri, mereno u smislu podržanih projekata, koje su prethodno pratila $i$ kreirala oba aktera (sve s obzirom na datum pre pokretanja analizirane inicijative) i kako to utiče na rezultat inicijative ili na prikupljeni kapital.

Ključne reči: Crovdsourcing - prikupljanje informacija, Crowfunding - platforme za grupno finansiranje, društveni kapital, zainteresovane strane, start-up, Ulule, Kickstarter 